\title{
Destructive Role of Radio in Society: Case Study of Pakistan (Malakand Region)
}

\author{
Musa Khan \\ Istanbul University Beyazit Turkey, Department of Radio, Television and Cinema \\ Email: Musakhan_85@yahoo.com \\ Nilüfer Pembecioğlu \\ Istanbul University Faculty of Communication, Radio Television Cinema Department \\ niluferpembecioglu@gmail.com
}

\section{Doi:10.5901/mjss.2015.v6n4s2p678}

\begin{abstract}
Media is an institution playing a key role in the construction or destruction of any society. Radio is an effective tool of Media that has a strong effect on the thoughts and behaviors of people and it plays an important role in the process of setting minds of people towards an issue both in positive or in negative way. In Malakand division of Pakistan where the literacy level is low, areas are vast and means of communication are insufficient, FM broadcasting is very effective, important and advance instrument due to the locality, closeness, quickness, easy access, easy operating, cheap, and large scale reach. In this research paper it has been investigated that radio has many effects on the behavior of people of this area. It has been also questioned and discussed that in the era of militancy FM radio played a negative role and misguided the innocent people of the area towards extremism and social instability. The FM broadcasting is used to change the mind and attitude of people towards extremism and insurgency. This study aims to find out the content of these FM stations and impacts on audience in the cited area. It is examined how the FM radios are used as a tool of war in the area by different groups and how these strongly affected the mind of innocent people of the area. Public perception indicates that FM stations delivered hatred information instead peace and development.
\end{abstract}

Keywords: Peace, Hatred Information, Misinterpretation Of Religion, State, Military, Extremism.

\section{Introduction}

The potential power of the media can transform and manipulate the whole nation especially in the developing countries it can be used as a 'Weapon of Mass Destruction'. According to different experts the most important use of media is to educate the people about the basic human rights. The dilemma of the developing countries is that people do not have the knowledge of their basic rights, even they don't know what to do and where to go to find solutions for their problems. Most of the residents of the developing countries are not aware about their communal strength.

FM broadcasting also called Community radio, which is a type of radio that offers a third model of radio broadcasting beyond commercial and public service. Community stations can serve geographic communities and communities of interest.

In Pakistan FM broadcasting is a popular and vital tool of media, which plays an important role in vast area of the country. Because of its locality it is getting much popularity in the country. Due to its easy access and cheap operation it can be very easily installed in any area of the country. This technology has the quality to attract and connect the local residents of the community which can be used for the advancement, development, education and entertainment of the local communities. FM technology has the quality to be operated easily by the operators and easily accessible to the audience.

Unfortunately Pakistan is one of those countries fighting the other's battle in their homeland. The story begins from 9/11 when USA attacked Afghanistan and Pakistan became its ally, since that time including all country FATA (Federally Administered Tribal Areas) and PATA (Provisionally Administered Tribal Areas) are suffering more. According to different media groups, analysts and government authorities, the different agencies of different countries playing their role in the destabilization of the country and insurgents groups started their activities with the misinterpretation of religion. Including other institutions insurgents snatched the media institutions especially FM Radios, and tried to influence and misguide the innocent people against state and military. 
Malakand was an administrative division of the Khyber Pukhtunkhwa (Old NWFP) province of Pakistan, until the improvements of 2000 ended the third level (rank) of government. This division includes seven northern districts of the province of Khyber Pukhtunkhwa which includes Lower Dir, Upper Dir, Swat, Bunir, Shangla, Malakand and Chitral. Two countries, Afghanistan are closed to this area in east while China also near to this division on north side. Because of its geographical placement, this division attracts many national and international political interests. In recent past this division has been suffered due to Afghan war.

As compare to other areas of the country the people of Malakand Division are more religious and majority of residents are Sunni Muslims. Traditionally the people of this area are so simple and have all the traditional characteristics of Pashtoon society. The inhabitants of the area are famous in hospitality, sincerity, simplicity and loyalty. Farming and laboring in foreign countries especially in KSA, UAE and Malaysia are the main sources of economy of the people of Malakand division. District Swat and Chitral are the famous districts for tourism but in resent past era, due to militancy it has been suffered and the income sources related to tourism fall dawn. The people of Malakand are keenly interested in getting education. But unfortunately sources of education are less in the area compared to the other areas of the country.

In Malakand region where literacy level is low the area is vast and means of communication are inadequate, FM broadcasting is a very effective instrument of mass communication due to its locality, closeness, quickness, easy access, easy operating, cheap, and infinite reach. In this region, due to its geographical environment and lack of social development, insurgents and some other groups easily used the FM broadcasting in the promotion of instability and extremism to influence the people with their ideas, which had a strong effect on the behavior of people of this region.

\subsection{Literature Review}

A vast research and studies have been conducted to examine the policies, agendas and impact of media (Radio) on the audience. They all tried to explore how media policies are shaped for a specific task to play role in the completion of these specific agendas, policies and targets. According to the Magic Bullet or Hypodermic needle Theory the media (magic gun) fired the message directly into the mind of the audience without their prior knowledge (Severin, 2001). The message causes the instant reaction in the mind of the audience without any hesitation. The media (needle) injects the message into the mind of the audience and this causes changes in behavior and psyche of the audience towards the message. The audience is mainly passive and they can't resist the media message (Croteau, Hoynes 1997). This theory deals with impact of media messages in the mind of the audience and how the audience reacts towards the message without any hesitation. According to this study the media information is active whereas the audience always remains passive. With the emergence of private Media in Pakistan, many practical examples have been noted during many moments. The media plays with the emotions and minds of people especially in the areas where literacy level is low and people have less awareness regarding media. Media consumers may become so overwhelmed by negative portrayals of crime and violence that they may begin -either cynically or despondently- to believe the real world is a mean and harsh place (Gerbner, et al. 1978); (Wilkinson \& Fletcher, 1995). Media plays an important role in the contextualization of values, beliefs and norms and ethics since our perception relies on media to get updated news and facts (Cordeiro, 2012). While the media is often criticized for their harmful effects, media can also be a positive avenue for learning and persuasion (Bryant \&Thompson, 2002). Media plays an important role to change the behavior of people. McCombs and Shaw assumed that "the mass media sets the agenda for political campaigns, influencing public attitudes toward desired issues" (Sadia, 2010). According to a special report of United State Institute of Peace (UNIP) normally media, in the form of radio, television, and newspapers mostly play a vital, positive and informative role in society. Sometimes it plays a negative role and manipulates the public on different issues. In this respect the role of media has many examples in the past, around the world. Media has been used as a tool to inflame grievances and increase violent conflict. Incident of the Rwanda is one of the examples where, radio was used to put down the basis for genocide. In the Former Republic of Yugoslavia, television was manipulated to fold ethnic tensions prior to civil war. Media also played a vital role in territorial disputes of former Soviet republic of Georgia (Mark \& Jonathan, 2003). According to this report responsibilities of media use on three parties: one is outlets themselves, the second one is concerning the professionals like journalists, editors, managers, etc. while the third responsible part is the government institutions dealing with media.

\subsection{Community Radio Effects}

The Importance and impacts of community radio can also be traced form western countries like US, UK and Belgium. According to a case study these countries updated their policies, contents regarding community radio and have been seen the legacy and struggle of community radio for their existence and survival. (Cammaerts, 2009). Even if the new 
media in the form of television, internet and social media etc, seems to be rapidly attracting the people and every new source of communication, entertainment and information replaced the old technology, still the community radio did not loose its importance specifically in such local areas. According to a research of the United States Agency for International Development, radio played a more effective role than television during awareness campaigns against HIVI AIDS. An analysis across the 27 sub-Saharam African countries the media exposure has been examined that the range of watching television from 7 percent in Chad to 75 percent in Ghana and Senegal, while for daily radio listening the range is from 12 percent in Ethiopia to 82 percent in Senegal. This study shows that different sources of media played an important role in the direction of increasing knowledge, preventive behavior and more affirming attitudes toward persons with HIVIAIDS. But as compared to television, radio exposure seems to have a greater impact. (Westoff, et all, 2011). Radio is an important type of media which plays a vital role in the mind setup and behavior change of the listeners. According to CIMA, the power of community radio to mobilize groups and bring change to societies is well recognized. This power can, however, also be manipulated and used to spread hate and violence, as was the case in Rwanda in 1994,( October 9 , 2007, the Center for International Media Assistance (CIMA), The Rwandan Genocide was the 1994 mass murder of an estimated 800,000 people in the small East African nation of Rwanda (JuvénalHabyarimana, et al 1995). According to some researchers the impact and importance of radio depends on the content and programs broadcasted and how much these are related and close to the target audiences. According to Mohammed, the massage of radio broadcasting always sent to an unorganized audience. The main assumption is that, weather the relevant massages are reaching to the relevant audience or not (Mohammed, 2013). Mohammed cited McAnany, who identified five strategies of utilization of radio in rural education and development. Open Broadcasting is one of the strategies for unorganized audience, while Instructional Radio can play an important role in the social change and development. This group, unlike the open broadcast strategy and target an organized learning group. Practical skills, civic responsibility, etc. can be taught to the specific group of audience and through feedback the impact can be estimated. Rural Radio Forum is another strategy for broadcasting which was started in Canada, and then spread to India and to some countries in Africa and Latin America. Such programs "Leads to changes in attitudes, behaviors, and practices" (Moemeka, 1994). Such programs include news stories, answers to listeners' queries, talks, discussion, etc. The target audience listens to the radio and then under the guidance of a group leader; makes dialogues on several related discussed issues. Radio Schools, Radio and Animation are the strategies through which illiterate adults can be educated promoting in local groups with the help of decision making leaders. Developing countries take more benefit from "Community Radio" as compared to developed nations. According to Madamombe a radio listner in Kolondieba said that "The radio has changed our lives. It makes us feel part of Mali," According to the listeners of radio in Africa they can keep their characters updated that what is happening around them (Madamombe, 2005). The listners further said that they really enjoy their local music and traditional programmes. These examples illustrate that radio will never loose its importance because of its easy access, especially in the developing countries of the world. Madamombe presented the importance of radio in Africa where the poor population can at least have an access to the different programms regarding basic information and traditional fun.

Radio, like other sources of media has a strong effect on the mind setting of audience and it can mold the opinion of listeners towards its designed agendas. According to Wabwire, in Kenya it has seems that vernacular FM stations played a vital role on different occasion. Vernacular means the common spoken language of a people, as distinct from formal written or literary language (Bing Dictionary). Since the post-election violence in Kenya, an ongoing debate took place on the role of FM Radios. Many stations have been charged because of fanned violence. Many people, including retired President Moi, demanded and have urged the authority's to prohibit these stations. Rural community radio in Kenya, according to the opinion of Moi is the vernacular station creating tribal chiefs, promoting disruptive politics and messages, and therefore could provoke anarchy (Wabwire, 2013). The role of these radios in Kenya can be compared to the FM Stations of Malakand region in Pakistan, where the same practice has been experienced. Instead of anarchy the insurgency sentiments can be traced while using of FM stations in Malakand, Pakistan.

Another debate that took place here is how the vernacular radio stations and community radio stations are differentiating from another. The common idea about community radio is that it is not for profit and it broadcasts socially useful massages for the development of community whereas the vernacular FM stations use the media for commercial purposes. The past philosophy of community radios are the voices of the voiceless and the representative of oppressed public. It should keep in mind that radio is a tool establishing a relation of sound with listeners. So its production must be catchy and attractive to get the attention of audience. Any static or motion pictures cannot be presented to audience, that means the format and production should fulfill the requirements of listeners (Mcleish, 2005). Radio importance cannot be ignored because it can easily attract the attention of people from those areas where access of other sources of media is limited. The contribution of community radio to encouraging media pluralism in Nepal can be pointed up by the example of Radio Sagarmatha, which broadcasts to the Kathmandu Valley. From the outset to the present day, Radio 
Sagarmathah as worked to present listeners a combination of issues and entertainment, social discussions and music offering a channel for a wide range of voices and opinions that were previously unheard on Nepal's radio channels (Pringle, 2008). In a broad perception, there are two dominant parts of radio, public and commercial, also playing an important role in depiction government's accountable, thus supporting democracy and fine governance. During last decades, community radio has changed into a new radio sector worldwide, as a natural result, both of the growth of civil societies and the breakthrough in communications technologies (Solervicens, 2007).

\section{Radio Broadcasting in Malakand Division Pakistan}

The Tehreek-e-Nafaz-e-Shariat-e-Mohammadi (TNSM) was first well-known in Swat in 1992 by a religious leader, MolanaSufi Muhammad. He demanded the introduction of an Islamic justice system and frequently repelled against official authority. This movement presented their demands in front of the authorities with the passage of time. The last attempt of this movement was comparatively harsh and they aggressively demanded for many things including their own judiciary system in the specific areas of the province. Some other religious leaders joined the movement and including the other sectors they started their preaching through media. Radio was an affective and easy tool for dissemination of information to maximum population, so they started the use of this tool and consequently they succeeded to spread their preaching to the majority of population. The Taliban leader of Swat, MaulanaFazlullah, also started an FM Radio station which was one of the famous radio stations of the area for preaching religious education. With the passage of time these preaching became harsh and hard. It became to be known as "Mullah Radio" as he continues the use of unauthorized transmissions on 92 megahertz. This technology is used easily and in a great amount because the technology to do so was very cheap and affordable, price as little as PKR 15,000 (less than USD 200) (Aziz, 2010). A survey has been conducted by a researcher for a FM radio of the area where the findings show that majority of the people believes that FM broadcasting helped the insurgents to promote their ideas and agendas. One of the main findings to appear from the survey was the active role played by the radio station in order to gain followers for their ideology, inform on laws, and also to act as a source for the collection of donations (Aziz, 2010). Unauthorized and Illegal FM radio is also booming in Khyber Agency, just to the west of Peshawar (capital of Khyber pukhtunkhwa). Here, a station is run by an activist commander, MangalBagh, of the Lashkar-e-Islam (LI, the Army of Islam). FM radio stations that more than 100 illegal and unauthorized FM radio stations have been operated in the tribal areas and throughout province of Khyber pukhtunkhwa, by heads of institutions, political and religious groups, which is rotating to be the key source of radicalizing the societies and seriously effect on the behavior and mind setting of people of this region (Khurshid, 2007). The easily controllable radios are busy in disseminating hatred rather than religious education. From Bajaur Agency to South Waziristan in FATA and Tank district to Swat and outside, a network of domestic FM radios is active every time to warn believable of the selfconceived conspiracies of the non-believers and the US-Islamic activities encouraged by opposing sects and groups at the behest of, what they call, Christians, Jews and Hindus. According to reports investigated by the intelligences, Swabi tops the rest of the province wherein these radios are operated in mosques and madrasas (Religious institutions). More than 98 per cent of the radios are operational in places of worship or where religious education is conveyed. These equipment requiring an amplifier, a mike and a receiver can easily be moved from one place to the other (Pakistan Defense, 2010).

It is clear from the above literature review that media plays a very effective role in mind setting of audience. The literature presents that during the era of militancy many FM stations were active in the transmissions of different ideas and propagation. Many researches and surveys regarding community radios have been discussed pointing out the importance and its effective role in the societies in different parts of the world. Some other type of research such as surveys and in-depth interviews were done on the area but they mentioned only the FM broadcasting and its work. This paper covers and questions the policies (agenda, programs, and target people), motives and its impact on the audience behavior located in the area.

\section{Aims and Methodology}

This study aims to find out the content of these FM stations and impacts on audience in the Malakand division of Pakistan where the literacy level is low, areas are vast and means of communication are insufficient, FM broadcasting is very effective, important and advance instrument due to the locality, closeness, quickness, easy access, easy operating, cheap, and large scale reach. In this research paper it has been investigated that radio has many effects on the behavior of people of this area. It has been also questioned and discussed that in the era of militancy FM radio played a negative role and misguided the innocent people of the area towards extremism and social instability. The 
FM broadcasting is used to change the mind and attitude of people towards extremism and insurgency.

The study concentrates on questioning how the FM radios are used as a tool of war in the area by different groups and how these strongly affected the mind of innocent people of the area. Public perception indicates that FM stations delivered hatred information instead peace and development.

\subsection{Hypothesis}

Public perception indicates that FM stations are mostly delivering hatred information instead of peace and development.

\subsection{Research Methodology}

The research design was both quantitative and qualitative, through the survey examined the opinion of radio listeners in Malakand division in the era of militancy. In this study the sample population was the residences of Malakand division, in both genders, including both educated as well as uneducated people.

The first step of research is to specify the focus group or unit of analysis. According to the Chudary (2007 p.14), "Population is the total set of interest that researcher wants to observe". The sample group used for analysis of this study includes different people of different ages, occupation and different education and income levels of Malakand division who were the listeners of FM radios in the era of militancy.

Through different age, occupation, education and income levels the study will easily reveal the contents of radios, public perceptions, impacts and behavior of different people of the area. According to the Chudhry (2007, p.15), "Sample is the subset of population". During the research, purposive sampling technique was used for data collection. Due to the limitation of time, resources and financial facilities it was not possible to meet the whole sample reaching to every person in population. To get the desired result within these limitations research is designed to get the information through a questionnaire form for four hundred people as the sample of the total population of Malakand Division which is 5.52 million.

\section{Data Analysis and Interpretation}

SPSS software (Statistical Package for Social Science) has been used for analyzing the results of collected data and presented the result with tabulation, frequency distribution, percentage, proportions, univariate and bivariate or cross tables. The outcomes of the study are presented in table charts. The tables presented the gender, age, occupation, education and income level of the listeners of the FM radios in the selected area. The main focus was the radio's content, its impact on the listeners and the aim was to find out the most listened radio stations. According to the Survey of BBC Pakistan in 2008, access of people to Media is as follows

Table -1. General Media Use in Pakistan

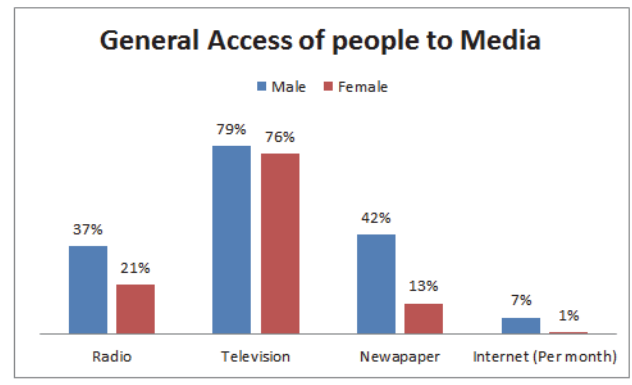

Table-1 presents the general media use in Pakistan. Radio listeners have the second big figure which shows the importance of this medium in a general context. 
Table -2. Gender wise distribution of Listeners in Chosen Area

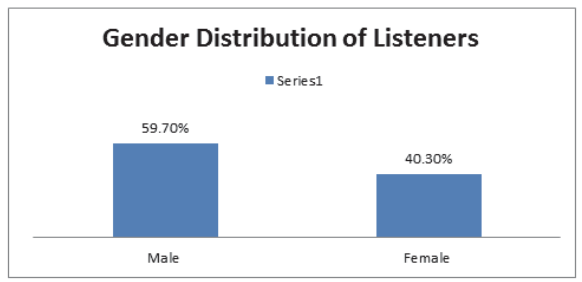

Table-2 presents the gender wise distribution of listeners in chosen area. To get the desired result throughout the data the sample group of the study is limited with the four hundred people out of the total population of the region reaching to 5.52 million. And the data is collected through the questionnaire form. The eligible responses of the questionnaire reached up to 357 out of the total number of four hundred. The sample aimed both male and female of every age, occupation, and education level to make sure to provide equal opportunity to both. But due to the traditions and strict cultural norms of the area it was impossible to reach to an equal participation level for both, so male respondents were 213 whereas female were 144 out of the total figure of 357 . That means the males are $59.7 \%$ and female are $40.3 \%$ out of the whole sample.

During the survey only the radio listeners were targeted from different classes of society such as students, businessmen, labors, drivers, servants, professionals and house wives. In the selected sample, often listeners of FM radios were shaping $48.2 \%$ of the whole sample, while the rare listeners are $30.5 \%$. 76 respondents namely $21.3 \%$ of the chosen sample replied that they listened to the radio seldom. 162 respondents (45.4\%) listened to the radio one hour on a daily basis. $25.2 \%$ of the participants were classified as the people spending 2 hours for listening to the radio and $17.9 \%$ of them was spending less than an hour while only $11.5 \%$ people listened to the radio more than 2 hours on daily basis. Time selection for listening to the radio by the respondents has also been questioned. $48.5 \%$ of the listeners were listening to the radio in evening time, 30\% preferred radio in morning and $20 \%$ at night while only $1 \%$ respondents reflected that they listened the radio in the afternoon.

The attention of listeners on radio program is questioned through a general question. The replies provide information on how much the audience was attentive on contents during listening to the radio. Majority of listeners (44.0\%) said that they listened to the radio individually while a close figure (42\%) spent time on listening radio with family. Only $8.7 \%$ respondents replied that they enjoyed the radio programs with friends and even a small number of $5.3 \%$ people said that they did not spend specific attention to radio consciously and they did other activities as well during listening.

Table -3. Age, Occupational, Educational and Income level distribution of the Respondents

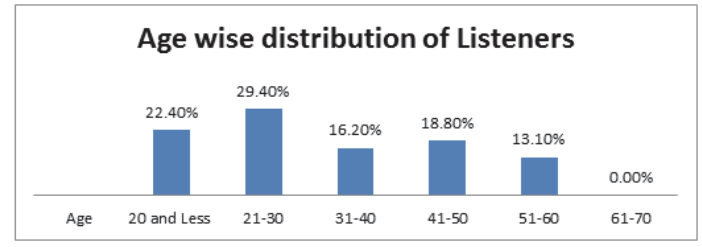

Table -4

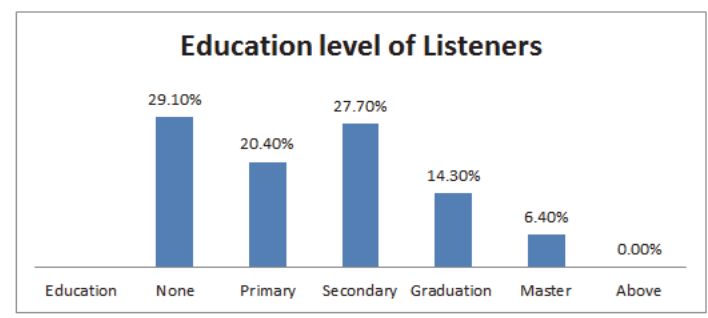


Table -5

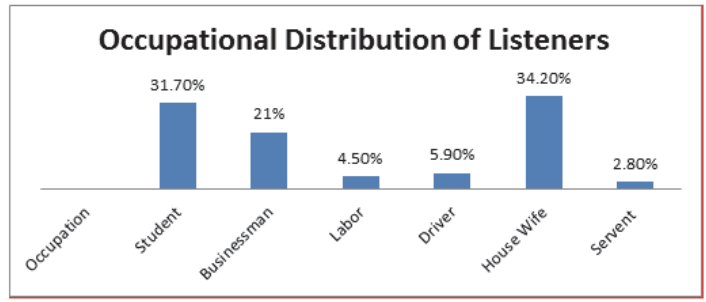

Table -6

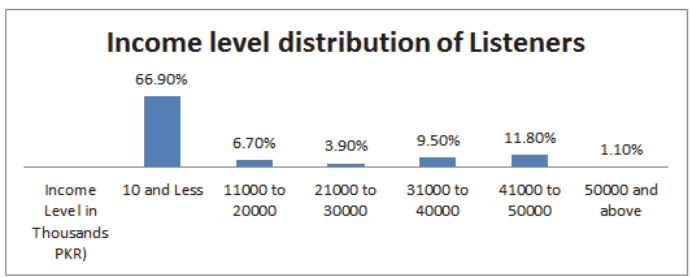

Table-3, 4, 5 and 6 are showing the age, occupational, educational and income level distribution of those people who responded the questionnaire. Tables indicate that $22.4 \%$ respondents belong to the age group of 20 or younger. $29.4 \%$ respondents belong to the age group $21-30,16.2 \%$ belong to the age group of 31-40, The age group 41-50 are 18.8 percent and $13.2 \%$ are belong to the aged group 51-60. According to selected sample majority of listeners are adolescents, which mean these people are the sensitive part of the society. Adolescents can easily be motivated in any revolution and can be put in a position to play a vital role in society and reshaping of existing system. According to the occupational distribution $34.2 \%$ percent of the respondents are housewives whereas $31.7 \%$ of the participants represent the second higher percentage as students. These rates indicate that majority of the sample involves women and students as listeners. Women are comparatively uneducated and they want to be in close contact with religion so they spend more time to listen to the radio due to because the fact that in the era of militancy the content of majority FM radios was religious. It also involves information on how easy it could be possible to motivate them through agenda setting information. Perhaps this could be the reason why women had contributed even their personal jewelries when Taliban demanded for Sadqa (Contribution) before starting violent activities. According to educational distribution $29.7 \%$ of the people have secondary school qualification whereas $29.1 \%$ of the whole respondents are illiterate. $20.4 \%$ of the people got only primary education. $14.3 \%$ respondents are graduates while $6.4 \%$ of participants are post graduates. It indicates that the youngsters are going to be educated while a great number of illiterate ones represented by housewives as majority,, The second reason why the illiteracy rate is so high is that the aged residents of the area did not get education due to lack of opportunities in the past. The distribution of the income level of the respondents shows the poverty of the residents of the area. $66.9 \%$ of the people are earning ten thousand or below, yet this figure also includes the students and housewives of the selected sample. Thus density of the students and housewives in the sample could also be the reason of low budget of majority of respondents. The remaining distribution of income level also seems to be unsatisfied because only $1.1 \%$ of the total respondents earn more than fifty thousand rupees, which is very small figure as compare to others.

Table -7. Delivered Programs by Most Listened Radios Stations

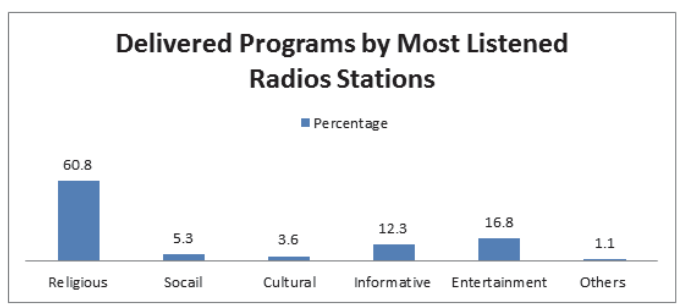


Table-7 Provides content information of the broadcasted programs by the most preferred radio stations. The table clearly shows that majority of FM radios presented religious programs. $60.8 \%$ respondents said that they focused on religious programs which follow the previous table-4.3, where the majority listeners spent time to FM Radios operated by Taliban or Political religious parties. The second highest figure is $16.8 \%$, showing entertainment programs, which indicated the listening of VOA or BBC by some number of listeners. Informative (12.3\%), social (5.3\%) and cultural (3.6\%) programs have lower respondents consecutively. This reveals the fact that content regarding cultural and social programs were very less in the cited era.

Table -8. The Content of Religious Programs

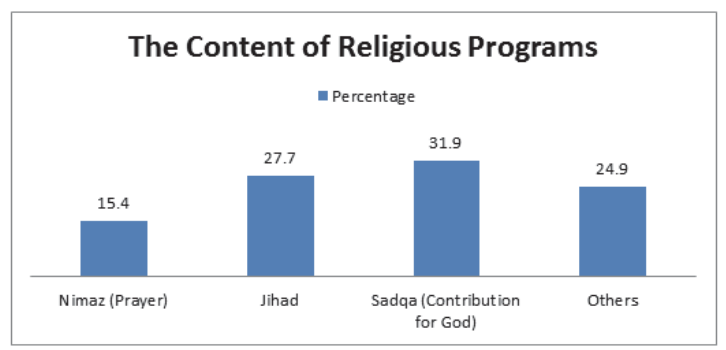

Table-8 Shows the content of religious programs broadcasted by different local FM Stations. As the previous table shows that majority of listeners followed the religious programs, so content of these programs were Jihad (Fight for Allah), Namaz (Prayer) and Sadqa (Contribution in the way of Allah). 31.9\% respondents is the highest figure of the selected sample replied that they listened most about Sadqa (Contribution in the way of Allah) while $27.7 \%$ people said that they frequently listen regarding Jihad (Fight for Allah). Both of these terms misinterpreted by Taliban leaders and paved the way to get their desirable achievements. Consequently they succeeded to some extent and manipulated the residents of the area to support their ideology. In different places of the Division especially in Swat Taliban collected a big amount of donation and influenced the audience that they are working to promote religion.

Table -10. Transmissions of FM Radios in Militancy's Era

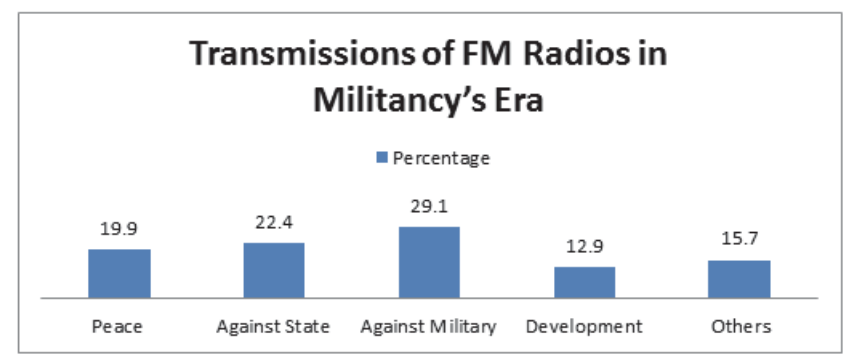

Table-10 indicates that the content of FM stations mostly delivered hatred information including transmission against state and military. $29.1 \%$ of the whole listeners stated that most transmissions were against Military. The second highest rate is $22.4 \%$ of the whole listeners according to whom FM radios spread information against the state. $19.9 \%$ of the people are in the favor of the disseminated information and consider it as peaceful while $12.9 \%$ of the respondents reflected their opinion that the delivered information played an important role in development. The research indicates that not all radios spread hatred information, while some played a comparatively better role in the society. Whereas total of hatred information against the state and military is summed up as $51.5 \%$ and this rate depicts that FM stations played a destructive role in the society trying to increase insurgency in the area. 


\subsection{Testing of Hypotheses}

For testing of hypothesis bivariate or cross table quantitative statistical method has been followed for the purpose of determining the empirical relationship between independent and dependent variables. The relationship of variables has been measured, that how both are simultaneously change together. Through comparison of both independent and dependent variables the presumptions of the study has been evaluated. The aim was to present the accurate findings collected by sampling of population through the survey.

Public perception indicates that FM stations delivered hatred information instead peace and development.

Table -11. Cross tabulation of variables

\begin{tabular}{|c|c|c|c|c|c|c|}
\hline \multirow{2}{*}{ Delivered Information } & \multicolumn{5}{|c|}{ Negative impact on People } & \multirow{2}{*}{ Total } \\
\hline & S. Agree & Agree & Neutral & Disagree & S. Disagree & \\
\hline Against Military & $51 \%(78)$ & $27.3 \%(30)$ & $33.3 \%(11)$ & $19.6 \%(9)$ & $26.7 \%(4)$ & $34.5 \%(132)$ \\
\hline Against State & $26.8 \%(41)$ & $32.7 \%(36)$ & $33.3 \%(11)$ & $23.9 \%(11)$ & $46.7 \%(7)$ & $29.7 \%(106)$ \\
\hline Peace & $11.8 \%(18)$ & $18.2 \%(20)$ & $21.2 \%(7)$ & $56.5 \%(26)$ & $13.3 \%(2)$ & $20.4 \%(73)$ \\
\hline Development & $10.5 \%(16)$ & $21.8 \%(24)$ & $12.1 \%(4)$ & $0 \%(0)$ & $13.3 \%(2)$ & $12.9 \%(46)$ \\
\hline Total & $42.9 \%(153)$ & $30.8 \%(110))$ & $9.2 \%(33)$ & $12.9 \%(46)$ & $4.2 \%(15)$ & $100 \%(357)$ \\
\hline \multicolumn{3}{|c|}{ Chi Square value $=67.160$} & \multicolumn{4}{|c|}{ Significance $=0.024$} \\
\hline \multicolumn{3}{|c|}{ Gamma value $=\quad-.279$} & \multicolumn{4}{|c|}{ Significance $=0.000$} \\
\hline
\end{tabular}

Table -11 presented the relation of two variables that the increasing of hatred information left negative impact on society. It seems that hatred information is an independent variable while negative impact is dependent. Here the hatred information disseminated by FM stations includes information against state, people and military. It has been compared with the disseminated information regarding peace and development. The cross table indicates that $78.3 \%$ of he listeners believe that most FM stations used hatred information against military which left a negative impact on society. 59.5\% of the listeners think that most FM stations used hatred information against state and people working with government institutions. 30\% of the respondents claimed that FM stations played an important role for peace in the area. The study covering different FM stations were operated by many groups from different locations, so all FM radios were not involved in the spreading of odium. $32.3 \%$ of the listeners feel that some radios played an important role in the development of society. Again it can be considered that some modern and community stations played a positive role on some people having a positive opinion. A big percentage of neutral opinion indicates that people either still feel threat and do not present their opinion on controversial issues or really are not aware in this perspective. As the whole table examined it might be declared that both variables have close relation with each other and high significance values $(0.024)$ and $(0.000)$ prove the positive dependency of variables on each other.

\section{Findings, Conclusion and Discussion}

Radio is an important tool of media which had played a vital role in every society since its invention. This media's tool helped in ideological objective and cultural exchanges for different nations in different eras. During Second World War it has been used for propagation by Nazis while the US took benefit from the tool against Soviet Union. US used the radio for propaganda in Afghanistan against Soviet Union during the war between capitalism and communism. The use of radio in Pakistan also has a great importance due to its locality and easy access to maximum population of the country. It is also in the position of the only accessible media by the masses. In Malakand division of KPK radio spent three regularize and non-regularize phases. In the first phase radio played a normal, ordinary and passive role before militancy and insurgency. This was the decade of 90 s and early 2000.

The second phase was very active and destructive, which could be defined as totally non-regularize age and radios were operated by different groups without any permission, licenses, ethics and laws. This research is based on second phase of the radio in the region of Malakand.

In Pakistan during militancy especially throughout late 2006 to early 2010 in Malakand regions radio has been used for different purposes by different groups to attract the people of the area toward their ideas and missions. It should be mentioned that either radio with legal or illegal status, has an impact on the audience which may develop a society or 
may destroy the good social values of the society. As in Malakand division FM radio station has passed through regularizing process both positive and negative ways as to be defined throughout the age. The findings of research reveal that during the era of militancy almost, overall FM radios played a negative role in society. Some traditional stations spread only hatred information against military and state. Mullah Radio (Swat), Commander Shahid FM, Commander JanatGul FM, Commander Shahid FM etc. were broadcasting to spread hatred information and always used a highly strong and tough language during transmission. According to some regular listeners and witnesses, these radios always threaten the people for different reasons. During live transmission these stations discussed the weapons and created a kind of threat for those people who were supporting the military or belonging to the governmental institutions. The presenters of radios, Mullah Fazllulah, Molana Shah dawran, MolanaAlam khan etc. always used the religious terms in their programs and misinterpreted these terms according to their agendas. They misinterpreted the term "Jihad" and hostile the people to join their group and fight against military and state. They never explain the real sense of term "Jihad" under which conditions and situations and to whom against should this fight be. They threatened the employees of government institutions to leave their duties and become a part of insurgency. They threatened even the common people of the area such as drivers, tailors for use of tape records in their vans and shops. They also disseminated information against the education of females. In all these broadcasted messages they claimed for implementation of "Shariah" (Islamic Law) but in-fact they never explained or acted according to Shariah.

It could easily be supposed through the examples that religion has been exploited by these FM stations and a negative portray of religion has been presented in front of the general audience, national and international communities.

The study has been examined that the people of different areas has diverse perceptions about FM radios in the area. This could be due to the different individual experiences and social support provided for a certain radio station. For example, Daroo FM Medan, MolanaHedayatullah FM Balambat, QaziFazlullah FM Timargara, had operated by political groups. Dr. Shawkat was the owner of DarooFm, who was a Homeopathic doctor and belongs to Muslim league Q. This FM station was totally a community radio and was popular among the public of local area because of its social, cultural and religious transmissions. MolanaHedayatullah belongs to Jamat-e-Islami, while QaziFazlullah belongs to JamiatUlmai-Islam, also had FM stations. These both FM stations presented totally religious programs as well as played a political role and tried to influence the people of the area toward their political thoughts. Both these stations were popular among the public for religious education and the housewives of the area listened more these stations to learn basic religious concepts. These stations did not misinterpret the religious terms but could not play any major or positive role in society. Radio Diwa (VOA) and BBC also have full access to the area and during the survey it has been observed that some people of area, especially adolescents were listeners of these international broadcasts. The content of these stations include social, cultural and entertainment programs. Comparatively listeners of these radios were fully satisfied but these stations also could not play any positive role on the society except so called social and cultural development.

\section{Recommendations}

The content of the broadcasting channel must be balanced like, social, cultural, entertainment, advertisement informative and educational programs should be included in the contents of FM Radios. FM stations should give focus to the local issues of the area and try to develop the society rather than playing a destructive role in society. Before operating a radio station in such areas, it would be better to conduct a survey to figure out the needs and expectations, the desire and requirements of the people of the area. Broadcasted content should formulate to fulfill the requirement and satisfaction of the people of the area. Not only to control the regulations but also to control the content, the government should give more focus on the media institutions for those areas where access to media is weak. One powerful aspect of the media is that it could easily be used as a propaganda tool and play a vital role in setting the mind of people, so effective organization and channels of media with advance and balanced content should be started, to educate, entertain and inform the people of regressive areas.

\section{References}

Abbas, H. (2006). Profile of Pakistan Seven Tribal Agencies. Washington: The Jamestown Foundation.

Aitken, H. G. (1985). The Continuous Wave: Technology and American Radio, 1900-1932. Princeton: Books on Demand.

Aitkin, H. G. (1985). The Continuous Wave: Technology and the American Radio, 1900-1932. Cristen: Princeton University Press.

Alam, M. A. (2009). PEMRA in Tribal Areas of Pakistan. www.Globalmedialaw.com.

Asa, B. A. (1995). Essentials of Mass Communication Theory. London: SAGE Publications.

Aziz, K. (2010). Swat: Main Causes of the Rise of Militancy. Oslo, Norway: Norwegian Institute of International Affairs. 
Ali, L. A., \& Khan, N. I. (2009). The Rise of Tehreek - e - e - ShariatNifaz - e-- Mohammadi in Malakand Division, NWFP: A Case Study of the Process od "State Inversion". Pakistan Version, 94.

Badsha, S. N., Farooq, H., Hifazatullah , H., Daar, N., \&Hamdani, K. U. (2012). Use of Electronic Media for Preaching of Religion in the light of Sharia.Asian Journal of Managment Sciences and Education, 124.

Baylis, J. and others (2008). Globalization of World Politics An Introduction to International Relations. London: Oxford.

Berger, A. A. (1995). Essentials of Mass Communication Theory. London: SAGE Publications.

Boyd-Barrett, Oliver \& Peter Braham (eds.) (1987): Media, Knowledge \& Power. London: Croom Helm

Cammaerts, B. (2009). Community Radio in the West: A legacy of struggle for survival in a state and Capitalist controlled media eviroment. International Communication gazette, 7-15.

Charles, W and Kegly, J. (2008). World Politics Trend and transformation. United State: Thomson Wadsworth.

Churchill, W. (2010). The story of the Malakand field force . Great Britain: Dover Publications.

Cohen, B. (1963). The Press and Foreign Policy. Princeton: NJ Princeton University Press.

Cordeiro, P. (2012, November). Radio becoming Radio: Covergence, interactivity and broadcasting trends in perspective. Participations Journal of Audience and Reception Studies, 9(2), 8.

Croteau, D. (1997). Industries and Audience Media/Society. London: PineForge Press.

Dallaire, Roméo; Beardsley, Brent (2003).Shake Hands with the Devil: The Failure of Humanity in Rwanda. New York City: Carroll \& Graf Publishers.

Dunaway, Ph.D., David (2002). Community Media in the Information Age: Perspectives and Prospects.Cresskill, NJ: Hampton Press).

Forest, L. D. (1950). Father of radio: the autobiography of Lee de Forest. Madison: Wilcox \& Follett.

Goldstein, J. S. and Pevehouse J. C. (2009). International Relations.United State New Jersey: Pearson.

Hanif, S. (2010). Importance of Media in Pakistan towards Change. Internet,www.Articlebase.com.

Haq, D. N., \& Imtiaz, Y. (2009). Swat Peace Accord. IPRI Fact File.

Hauss, C. (2010). International Conflict Resolution.New York: The Continuum International Pulication.

Hoynes, W. (1997 ). Industries and Audience Media/Society. London: Pine Forge Press.

Khan, K. (2007). Illegal FM Radios Spreading Hatred. peshawar: Published by Dalily Times Friday, August 10, 2007, Internet. www.valleyswat.net/articles/fm_radios.html

Kleinnijenhuis, J. \& Rietberg, E.M. (19̄95). Parties, media, the public and the economy: Patterns of societal agenda-setting. European journal of political research: official journal of the European Consortium for Political Research.

Madamombe, I. (July, 2005). Community radio: a voice for the poor. Africa Renewal (Online) , 4.

Malik, S. (2013). Media and Militancy: Case Study of Use of FM Radio by Taliban in Swat. IPRI, 88-89.

Mark, F., \& Jonathan, T. (2003). Use and Abuse of Media in Vulnerable Societies. Washington, DC: UNITED STATES INSTITUTE OF PEACE.

Mcleish, R. (24 May, 2005). Radio Production (5 edition ed.). Great Britain: Focal Press.

Moemeka, A. (1994). Communicating for Development: A New Pan-Disciplinary Perspective, State University of New York Press: USA.

Mohammed, J. (2013). Challenges and Opportunities in the Use of Radio Broadcast for Development in Ethiopia: Secondary Data Analysis. Online Journal of Communication and Media Technologies, 3 (3), 9-16.

Mtimde, L. (1998). What Is Community Radio . South Africa: AMARC Africa Panos Southern Africa.

McCombs, M. E. (2004). Setting the agenda: the mass media and public opinion. Texas Austin.: Polity Publisher.

Naz, D. A. (2008). Fm Radio Revolution In Pakistan. Global Media Journal Pakistan Edition.

O'Neil, P. H. (2007). Essentials of Comparative Politics.New York: W. W. Norton \& Company

Pakistan Broadcasting Corporation Act, 1973 (XXXII of 1973)

Pringle, I. (2008). Pioneering Community Radio Impacts of IPDC Assistance in Nepal. Paris : UNESCO IPDC

Siemering, W. (2007). Community Radio: Its Impact and Challenges to its Development. Washington: Center for International Media Assistance.

Solervicens, M. (2007). Community Radio Social Impact Assessment Removing Barriers Increasing Effectiveness. Montréal(Québec) Canada: AMARC Global Evaluation

Wabwire, J. (2013). The Role of Community Radio in Develpment of Rural Poor . New media and Mass Communication(Online) , 44-45.

Westoff, C. F., Koffman, A. D., \& Moreau, C. (December 2011). The Impact of Television and Radio on Reproductive Behaviour and on HIVIAIDS knowledge and Behaviour. ICF International, Calverton, Maryland . Princeton, New Jersey: Princeton University.

Wilkinson, J. S., \& Fletcher, J. E. (1995). Bloody news and vulnerable populations: An ethical question. Journal of Mass Media Ethics,10:3, 167. 